\title{
Regresi Tersegmen dengan Titik Patahan Diketahui
}

\author{
Charles E. Mongi ${ }^{1}$ \\ ${ }^{1}$ PS Matematika FMIPA Universitas Sam Ratulangi Manado, charlesmongi@ymail.com
}

\begin{abstract}
Abstrak
Penggunaan analisis regresi diharapkan akan mendapat model regresi yang menjelaskan sebanyak mungkin informasi yang ada pada data. Akan tetapi belum tentu model yang telah dispesifikasikan tersebut cocok dengan data. Dengan demikian satu model kurang sesuai sehingga dibutuhkan beberapa submodel. Model regresi linier tersegmen terdiri dari beberapa submodel linier, bila digambarkan model ini berupa rangkaian garis linier yang patah-patah. Model ini bisa digunakan sebagai pendekatan terhadap bentuk kurva model regresi tidak linier. Hasil analisis regresi linier tersegmen memberikan nilai koefisien determinasi lebih besar dibandingkan model regresi linier sederhana, yang berarti bahwa model regresi linier tersegmen mampu menjelaskan keragaman data lebih besar dari keragaman yang bisa dijelaskan oleh model regresi linier sederhana. Selain itu, untuk kasus ini regresi tersegmen dengan fungsi tidak kontinu lebih baik dari regresi tersegmen dengan fungsi kontinu.
\end{abstract}

Kata kunci: Regresi Tersegmen, Titik Patahan.

\section{Segmented Regression with a Given Breakpoint}

\begin{abstract}
Utilization of regression analysis is expected in order to obtain a regression model that explains as much information as possible on the data. However, the specified model fits the data is uncertain. Thus, the use one model will be less appropriate, so that required some submodel. Segmented linear regression model consists of several sub-linear model that described in the form of a series of faltering linear lines. This model can be used as an approach towards shape of not-linear regression curve. Segmented linear regression analysis provide larger coefficient of determination than the simple linear regression model, which means that the segmented linear regression model is able to explain the diversity of data of more than diversity that can be described by a simple linear regression model. In this case, segmented regression with uncontinuous function is better than segmented regression with continuous function.
\end{abstract}

Keywords : Segmented Regression, Breakpoint.

\section{Pendahuluan}

\subsection{Latar Belakang}

Analisis regresi digunakan untuk menggambarkan hubungan antara peubah respon Y dengan peubah penjelas $\mathrm{X}$ dalam suatu bentuk model regresi, dengan harapan model tersebut dapat menjelaskan sebanyak mungkin informasi yang ada pada data. Akan tetapi, belum tentu model yang telah dispesifikasikan tersebut cocok dengan data. Hal ini bisa saja dikarenakan setelah nilai $\mathrm{X}$ tertentu, titik-titik data pengamatan berada jauh dari garis regresi, atau dengan kata lain peubah respon menunjukkan pola yang berbeda setelah nilai $\mathrm{X}$ tertentu. Dengan demikian, satu model kurang sesuai jika digunakan untuk mewakili hubungan antara peubah respon dan peubah penjelas. Sehingga, dibutuhkan suatu model yang terdiri dari beberapa submodel, dimana masing -masing submodel digunakan pada rentang nilai $\mathrm{X}$ yang berbeda.

Analisis regresi linier sederhana, model regresi digambarkan sebagai sebuah garis linier. Analisis ini bisa dilakukan terhadap seluruh data atau pun membagi nilai-nilai peubah penjelas menjadi beberapa bagian (segmen) kemudian menerapkan analisis regresi pada setiap segmen, yang dikenal dengan analisis regresi linier tersegmen (Segmented Linear Regression) [1]. Model regresi linier tersegmen terdiri dari beberapa submodel linier, bila digambarkan model ini berupa rangkaian garis linier yang patah-patah. Oleh karena itu, model ini bisa digunakan sebagai pendekatan terhadap bentuk kurva model regresi yang tidak linier.

Analisis regresi linier tersegmen, terdapat suatu titik yang disebut breakpoint, yaitu titik batas antar tiap segmen (titik patah). Pada titik ini diduga mulai terjadi perubahan 
bentuk hubungan matematis antara peubah respon dengan peubah penjelas. Titik ini juga digunakan sebagai indikator banyaknya segmen (s), di mana s = banyaknya breakpoint +1 .

\subsection{Tujuan}

Tujuan adalah untuk mengkaji analisis regresi linier tersegmen sebagai pendekatan linier untuk pasangan data yang mempunyai kecenderungan bentuk kurva model regresi yang tidak linier.

\section{Bentuk Model Regresi Linier Tersegmen}

Model regresi linier tersegmen adalah model regresi yang terdiri dari dua submodel yang bersifat linier. Model ini banyak digunakan di berbagai bidang, seperti ekonomi, kedokteran dan lain sebagainya dan digunakan apabila terdapat indikasi perubahan parameter setelah nilai tertentu pada peubah penjelas. Dengan demikian, nilai-nilai pada peubah penjelas terbagi menjadi dua bagian (segmen).

Secara umum, model regresi linier tersegmen dibagi menjadi dua tipe, yaitu model regresi yang kontinu, dimana model regresi linier di segmen pertama bertemu dengan model regresi linier di segmen kedua pada breakpoint, seperti tampak pada Gambar 1a dan 1b dan model regresi yang tidak kontinu, dimana model regresi linier di segmen pertama tidak bertemu dengan model regresi linier di segmen kedua pada breakpoint, seperti terlihat pada Gambar 1c dan 1d [2].

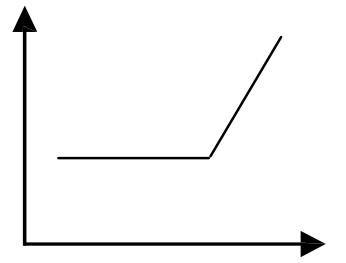

a. Regresi linier tersegmen yang kontinu pada breakpoint dengan slope $1=0$ dan slope $2>0$

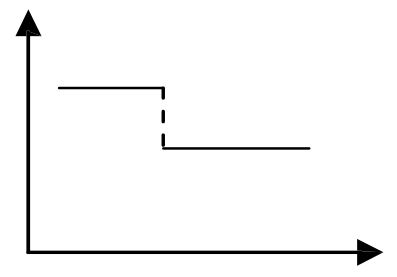

c. Regresi linier tersegmen yang tidak kontinu pada breakpoint dengan slope $=0$

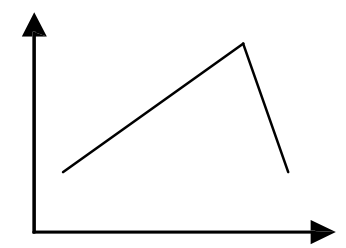

b. Regresi linier tersegmen yang kontinu pada breakpoint dengan slope $1>0$ dan slope $2<0$

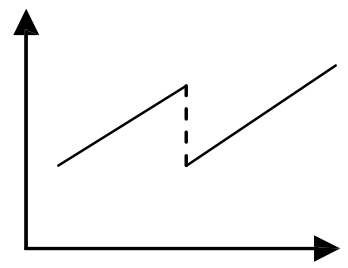

d. Regresi linier tersegmen yang tidak kontinu pada breakpoint dengan slope 1 dan slope $2>0$

Gambar 1. Bentuk fungsi regresi linier tersegmen

Secara khusus, ada 7 tipe model pada analisis regresi linier tersegmen, yaitu:

1. Tipe 0 - sebuah garis horizontal tanpa breakpoint;

2. Tipe 1 - sebuah garis miring tanpa breakpoint (seperti garis regresi linier sederhana);

3. Tipe 2 - garis miring pada segmen pertama dan kedua (seperti Gambar 2.2b);

4. Tipe 3 - garis horizontal pada segmen pertama dan garis miring pada segmen kedua (seperti Gambar 2.2a);

5. Tipe 4 - garis miring pada segmen pertama dan garis horizontal pada segmen kedua;

6. Tipe 5 - garis horizontal pada segmen pertama dan kedua dengan level yang berbeda (seperti Gambar 2.2c);

7. Tipe 6 - dua garis miring yang terpisah (seperti Gambar 2.2d).

Model yang telah diduga digunakan untuk memprediksi perilaku sistem yang diamati, bukan meramalkan. Istilah prediksi mempunyai arti khusus yaitu interpolasi, yakni mencari suatu nilai fungsi yang tidak diketahui di antara beberapa nilai fungsi yang diketahui. 


\section{Analisis Regresi Linier Tersegmen (Segmented Linear Regression)}

Analisis regresi linier tersegmen adalah suatu metode dalam analisis regresi yang membagi peubah penjelas menjadi beberapa segmen berdasarkan nilai tertentu yang disebut dengan breakpoint dimana, pada setiap segmen data terdapat model regresi linier [1].

Analisis regresi linier tersegmen dengan satu breakpoint disebut juga dengan analisis regresi linier dua fase. Pada metode ini, garis regresi tidak lagi disajikan dalam satu garis linier, melainkan disajikan dalam dua garis linier yang ber temu pada suatu titik, yaitu titik $\mathrm{x}=\mathrm{c}$. Dengan demikian, terdapat dua model regresi berikut:

$$
\begin{array}{ll}
Y=a_{1}+b_{1} X & x \leq c \\
Y=a_{2}+b_{2} X & x \geq c \\
\text { Pada saat titik } x=c, & \\
a_{1}+b_{1} c=a_{2}+b_{2} c &
\end{array}
$$

di mana, titik $\mathrm{x}=\mathrm{c}$ disebut sebagai breakpoint.

Persamaan 2.1 juga dapat dituliskan dalam bentuk:

$$
a_{2}=a_{1}+c\left(b_{1}-b_{2}\right)
$$

Jika $\mathrm{a}_{2}$ disubstitusikan ke model regresi $\mathrm{Y}=\mathrm{a}_{2}+\mathrm{b}_{2} \mathrm{X}$, maka akan diperoleh bentuk lain dari model analisis regresi linier tersegmen yaitu:

$$
\begin{array}{ll}
\mathrm{Y}=\mathrm{a}_{1}+\mathrm{b}_{1} \mathrm{X} & \mathrm{x} \leq \mathrm{c} \\
\mathrm{Y}=\left\{\mathrm{a}_{1}+\mathrm{c}\left(\mathrm{b}_{1}-\mathrm{b}_{2}\right)\right\}+\mathrm{b}_{2} \mathrm{X} & \mathrm{x} \geq \mathrm{c} \quad \text { [5]. }
\end{array}
$$

Analisis regresi linier tersegmen, breakpoint bisa saja sudah diketahui sebelum analisis. Tapi, pada umumnya titik ini tidak diketahui dan harus diduga terlebih dahulu.

\section{Pendugaan Kuadrat Terkecil}

Misalkan terdapat suatu model regresi dua fase:

$$
\mathrm{Y}_{\mathrm{si}}=\alpha_{\mathrm{s}}+\beta_{\mathrm{s}} \mathrm{x}_{\mathrm{si}}+\varepsilon_{\mathrm{si}} \quad \mathrm{i}=1,2, \ldots, \mathrm{n}_{\mathrm{s} ; \mathrm{s}=1,2}
$$

dengan $\mathrm{x}_{[11]}<\mathrm{x}_{[12]}<\ldots<x_{\left[1 n_{1}\right]}<c<\mathrm{x}_{[21]}<\mathrm{x}_{[22]}<\ldots<x_{\left[2 n_{2}\right]}$ dan $c$ diketahui, dimana:

$\mathrm{x}_{[\mathrm{si}]} \quad=$ nilai peubah penjelas yang telah diurutkan dari nilai terkecil ke nilai terbesar

$c \quad=$ breakpoint

$\mathrm{n}_{\mathrm{s}} \quad=$ banyaknya pasangan data pada segmen $\mathrm{ke}-\mathrm{s}$

$\mathrm{s} \quad=$ banyaknya segmen

Jika breakpoint diketahui, maka pendugaan parameter model regresi linier tersegmen dilakukan dengan metode kuadrat terkecil terkendala (MKTK) dengan kendala pada persamaan (1), yang diselesaikan dengan metode Lagrange. Sehingga, jumlah kuadrat sisa pada model regresi linier tersegmen, adalah:

$$
J K_{S K}=\sum_{s=1}^{2} \sum_{i=1}^{n_{s}}\left(y_{s i}-\propto_{s}-\beta_{s} x_{s i}\right)^{2}+2 \lambda\left(\alpha_{2}-\alpha_{1}+c\left(\beta_{2}-\beta_{1}\right)\right)
$$

$-2 \lambda$ adalah pengganda Lagrange. Setelah menurunkan $\mathrm{JK}_{\mathrm{SK}}$ terhadap $\alpha_{\mathrm{s}}, \beta_{\mathrm{s}}$ kemudian disamakan dengan nol, diperoleh persamaan:

$$
\begin{aligned}
& -2\left(\sum_{i} y_{1 i}-n_{1} \tilde{\alpha}_{1}-\sum_{i} x_{1 i} \tilde{\beta}_{1}\right)-2 \lambda=0 \\
& -2\left(\sum_{i} y_{2 i}-n_{2} \tilde{\alpha}_{2}-\sum_{i} x_{2 i} \tilde{\beta}_{2}\right)+2 \lambda=0 \\
& -2\left(\sum_{i} x_{1 i}\left(y_{1 i}-\tilde{\alpha}_{1}-\sum_{i} \tilde{\beta}_{1} x_{1 i}\right)\right)-2 \lambda c=0 \\
& -2\left(\sum_{i} x_{2 i}\left(y_{2 i}-\tilde{\alpha}_{2}-\sum_{i} \tilde{\beta}_{2} x_{2 i}\right)\right)+2 \lambda c=0
\end{aligned}
$$

Dari persamaan (2) dan (3) didapatkan:

$$
\tilde{\alpha}_{s}=\bar{y}_{s}-\tilde{\beta}_{s} \bar{x}_{s}+(-1)^{s-1} \lambda n_{s}^{-1}
$$

$\tilde{\alpha}_{s}, \tilde{\beta}_{s}$ adalah penduga parameter $\alpha_{\mathrm{s}}, \beta_{\mathrm{s}}$ dari metode kuadrat terkecil terkendala.

Dengan mensubtitusikan persamaan (6) ke dalam persamaan (1) diperoleh:

$$
\lambda=w\left\{\bar{y}_{2}-\bar{y}_{1}+\widetilde{\beta}_{1}\left(\bar{x}_{1}-c\right)-\tilde{\beta}_{2}\left(\bar{x}_{2}-c\right)\right\}
$$

dimana: $\mathrm{w}=\frac{n_{1} n_{2}}{\left(n_{1}+n_{2}\right)}$ 
Selanjutnya, substitusi persamaan (6) dan (7) ke persamaan (4) dan (5), menghasilkan sistem persamaan untuk menghitung nilai $\widetilde{\beta}_{S}$ :

dimana: $c_{s s}=\sum_{i}\left(x_{s i}-\bar{x}_{s}\right)^{2}+w\left(\bar{x}_{s}-c\right)^{2}$

$$
\begin{aligned}
& c_{11} \tilde{\beta}_{1}+c_{12} \tilde{\beta}_{2}=c_{13} \\
& c_{21} \tilde{\beta}_{1}+c_{22} \tilde{\beta}_{2}=c_{23}
\end{aligned}
$$

$c_{12}=c_{21}=-w\left(\bar{x}_{i}-\gamma\right)\left(\bar{x}_{2}-c\right)$ dan

$c_{s 3}=\sum_{i}\left(y_{s i}-\bar{y}_{s}\right)\left(x_{s i}-\bar{x}_{s}\right)+(-1)^{s} w\left(\bar{y}_{2}-\bar{y}_{1}\right)\left(\bar{x}_{s}-c\right)$

Setelah $\tilde{\beta}_{1}$ dan $\tilde{\beta}_{2}$ diketahui, diperoleh nilai $\lambda$ pada persamaan (7) dan $\tilde{\alpha}_{s}$ pada persamaan (6). Dengan demikian,nilai minimum $\varepsilon^{\prime} \varepsilon$ adalah:

$$
\begin{aligned}
& \sum_{s=1}^{2} \sum_{i=1}^{n_{s}}\left(y_{s i}-\tilde{\alpha}_{s}-\tilde{\beta}_{s} x_{s i}\right)^{2} \\
= & \sum \sum\left\{y_{s i}-\bar{y}_{s}-\tilde{\beta}_{s}\left(x_{s i}-\bar{x}_{s}\right)+(-1)^{s} \lambda n_{s}^{-1}\right\}^{2} \\
= & \sum \sum\left(y_{s i}-\tilde{y}_{s}\right)^{2}-2 \sum \sum \tilde{\beta}_{s}\left(y_{s i}-\tilde{y}_{s}\right)\left(x_{s i}-\bar{x}_{s}\right)+\sum \sum \tilde{\beta}_{s}^{2}\left(x_{s i}-\bar{x}_{s}\right)^{2}+\frac{\lambda^{2}}{w}
\end{aligned}
$$

yang selanjutnya disebut $\mathrm{JK}_{\mathrm{SK}}[3][4][6]$.

\section{Hasil dan Pembahasan}

Contoh data bahan mentah dengan biaya adalah peubah respon $(\mathrm{Y})$ dan ukuran pengiriman adalah peubah penjelas (X), seperti dalam Tabel 1. Dari data dalam Tabel 1 kemudian dibuat diagram pencar seperti pada Gambar 2.

Tabel 1. Data dengan peubah respon dan peubah penjelas

\begin{tabular}{|c|c|}
\hline $\mathbf{Y}$ & $\mathbf{X}$ \\
\hline 2.57 & 650 \\
\hline 4.40 & 340 \\
\hline 4.52 & 400 \\
\hline 1.39 & 800 \\
\hline 4.75 & 300 \\
\hline 3.55 & 570 \\
\hline 2.49 & 720 \\
\hline 4.27 & 480 \\
\hline 4.42 & 425 \\
\hline 4.10 & 460 \\
\hline 2.21 & 675 \\
\hline 2.90 & 600 \\
\hline
\end{tabular}

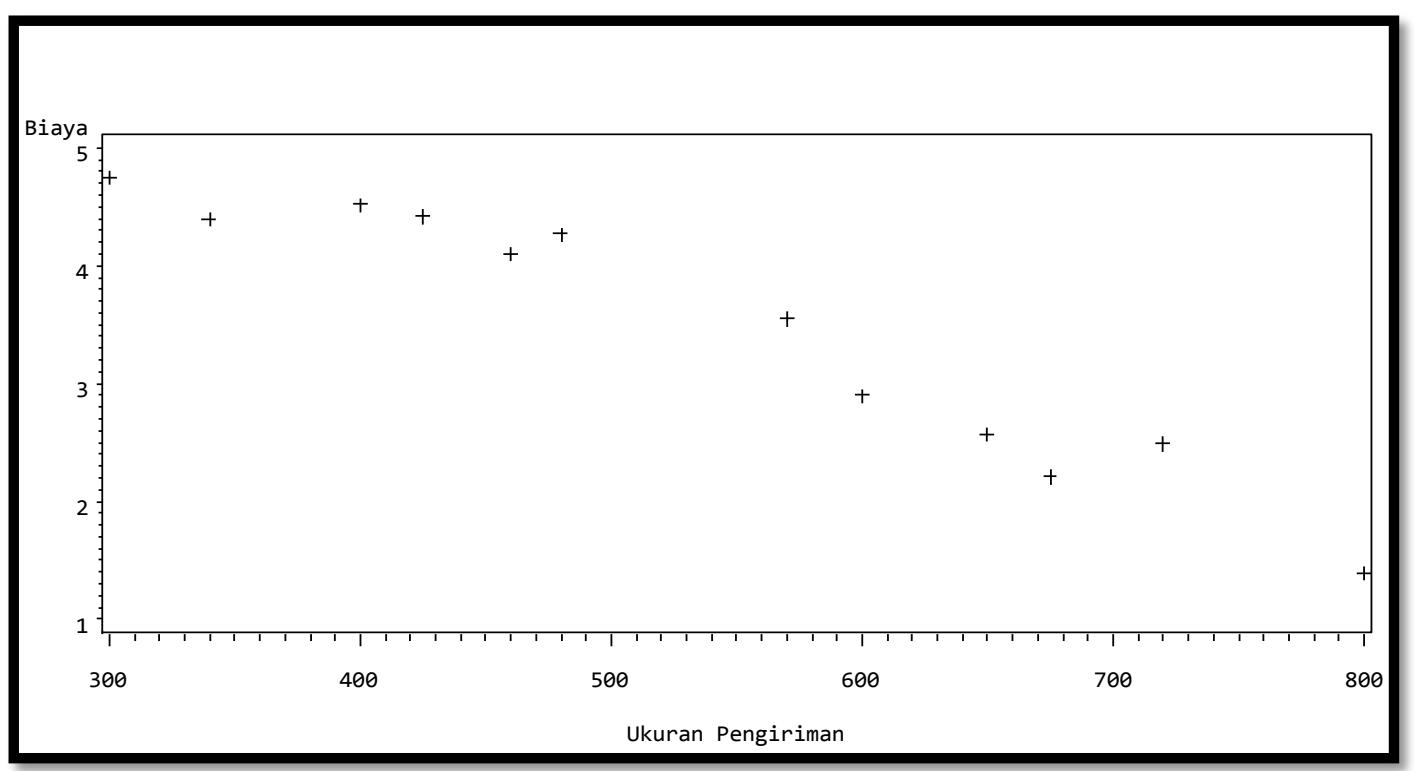

Gambar 2 Diagram Pencar antara peubah respon dan peubah penjelas 
Dengan analisis regresi linear sederhana hasilnya seperti dalam Tabel 2.

Tabel 2. Hasil analisis regresi linier sederhana

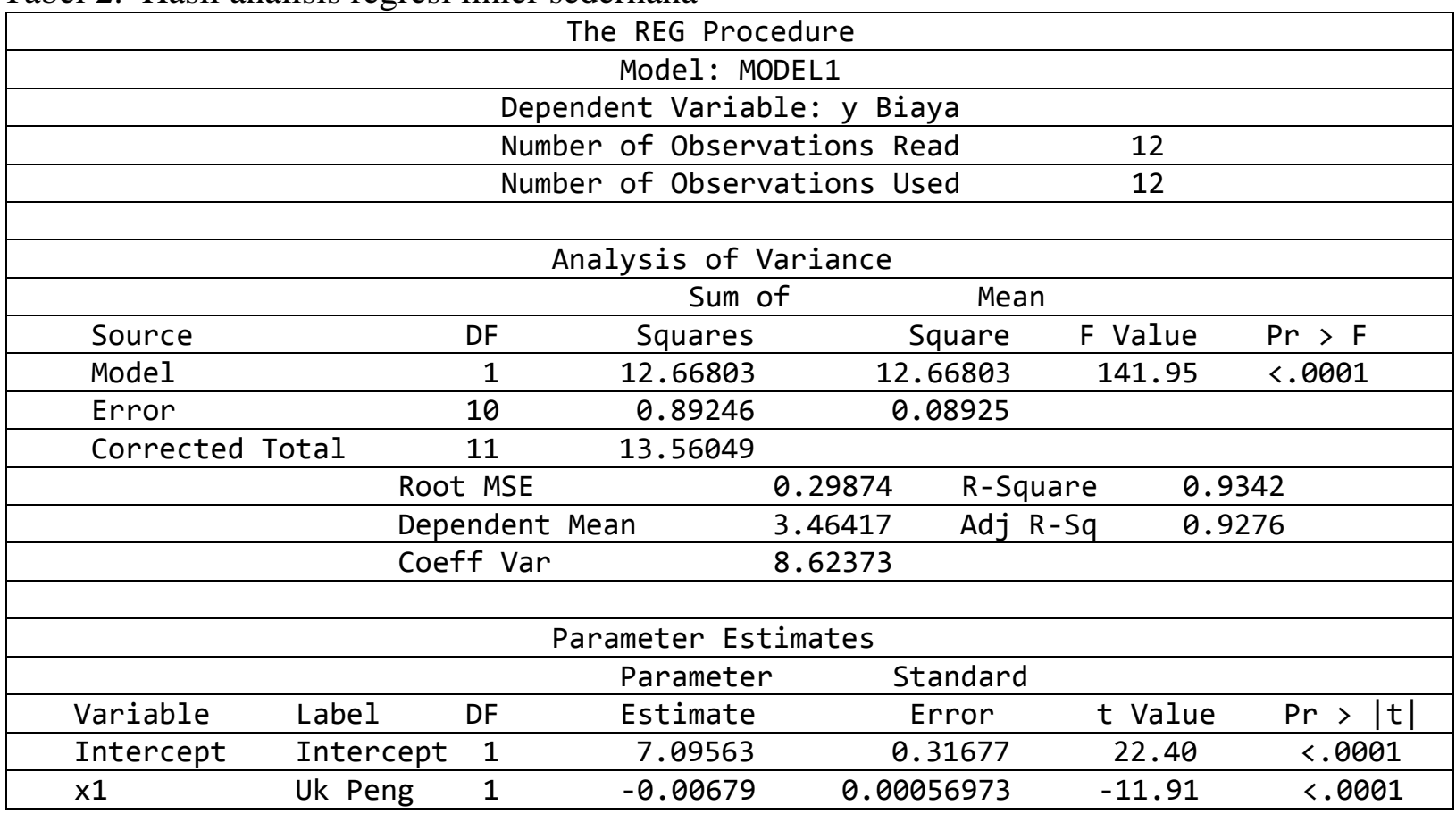

\subsection{Regresi Tersegmen Fungsi Kontinu}

Dengan analisis regresi tersegmen untuk titik patahan pada $X=500$ hasilnya seperti dalam Tabel 3 (fungsi yang kontinu).

Tabel 3. Hasil analisis regresi linier tersegmen fungsi kontinu

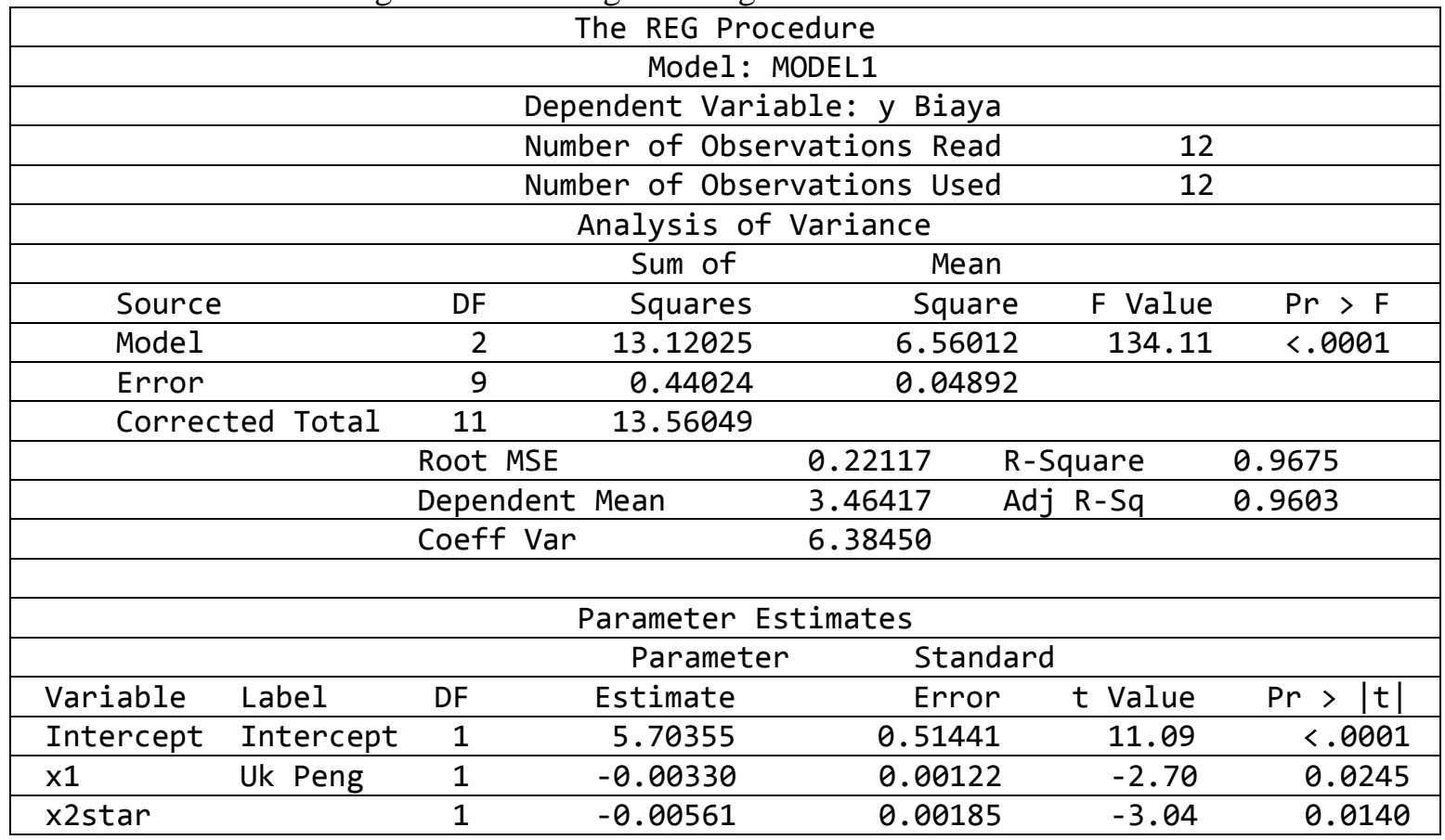

Hasil kedua analisis tersebut nilai $\mathrm{R}^{2}$ seperti dalam Tabel 4. Nilai $\mathrm{R}^{2}$ untuk regresi tersegmen lebih besar dari dari regresi linear sederhana. Hasil plot regresi tersegmen dengan titik patahan $\mathrm{X}=500$ seperti dalam Gambar 3. 
Tabel 4. Nilai $\mathrm{R}^{2}$ untuk masing-masing analisis regresi

\begin{tabular}{|l|c|}
\hline \multicolumn{1}{|c|}{ Hasil Analisis } & $\mathrm{R}^{2}$ \\
\hline Regresi Linear Sederhana & 0.9342 \\
\hline Regresi Tersegmen & 0.9675 \\
\hline
\end{tabular}

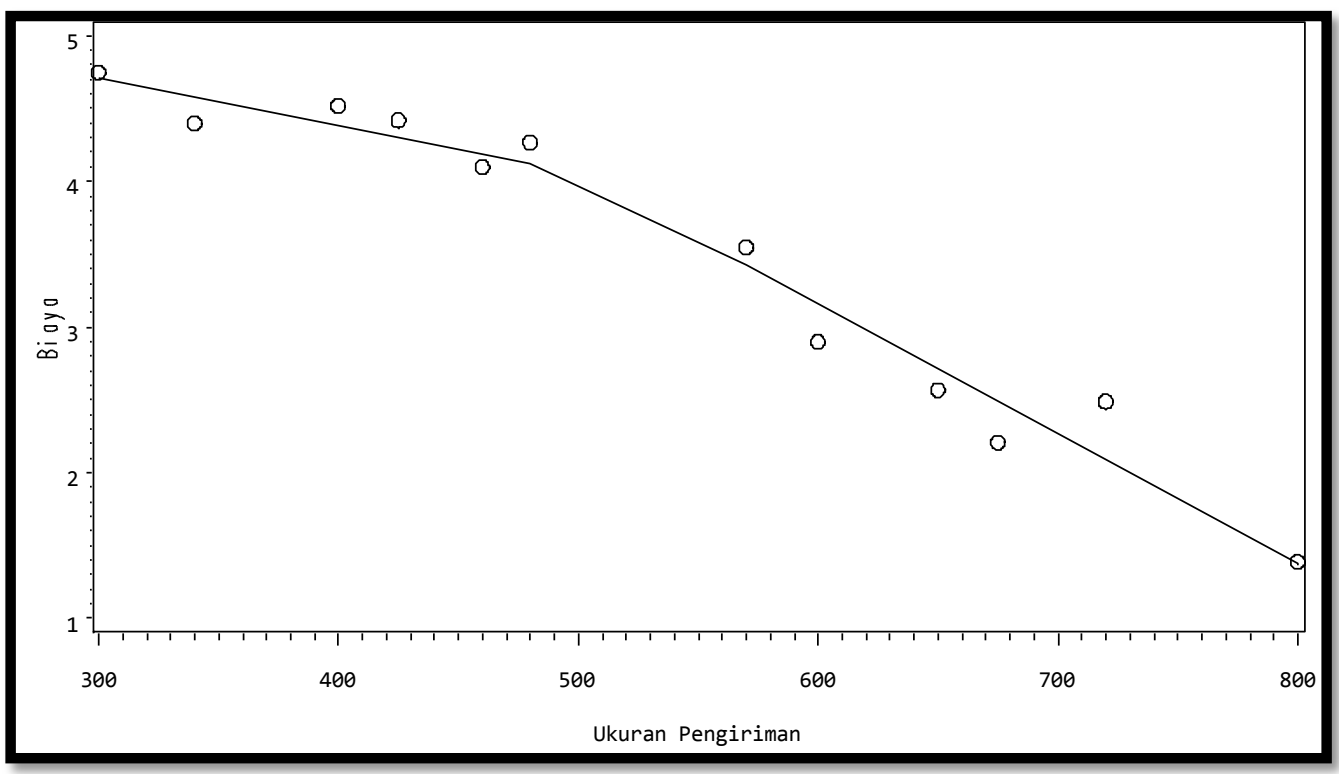

Gambar 3 Plot regresi tersegmen fungsi kontinu

\subsection{Regresi Tersegmen Fungsi tidak Kontinu}

Hasil analisis regresi tersegmen untuk titik patahan pada $X=500$ hasilnya seperti dalam Tabel 5 (fungsi yang tidak kontinu). Plot regresi tersegmen dengan titik patahan $X=500$ seperti dalam Gambar 4.

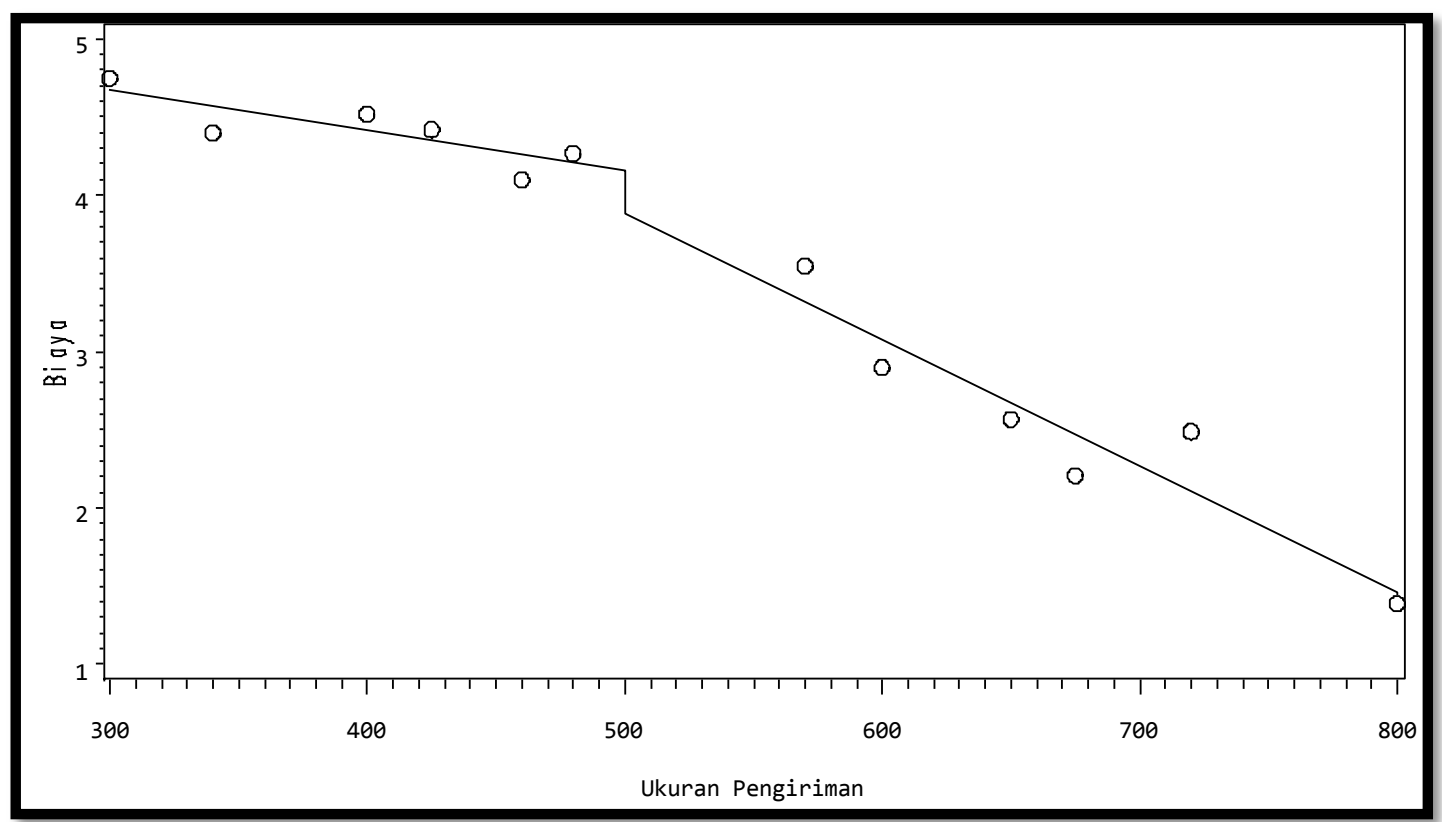

Gambar 4. Plot regresi tersegmen fungsi tidak kontinu 
Tabel 5. Hasil analisis regresi linier tersegmen fungsi tidak kontinu

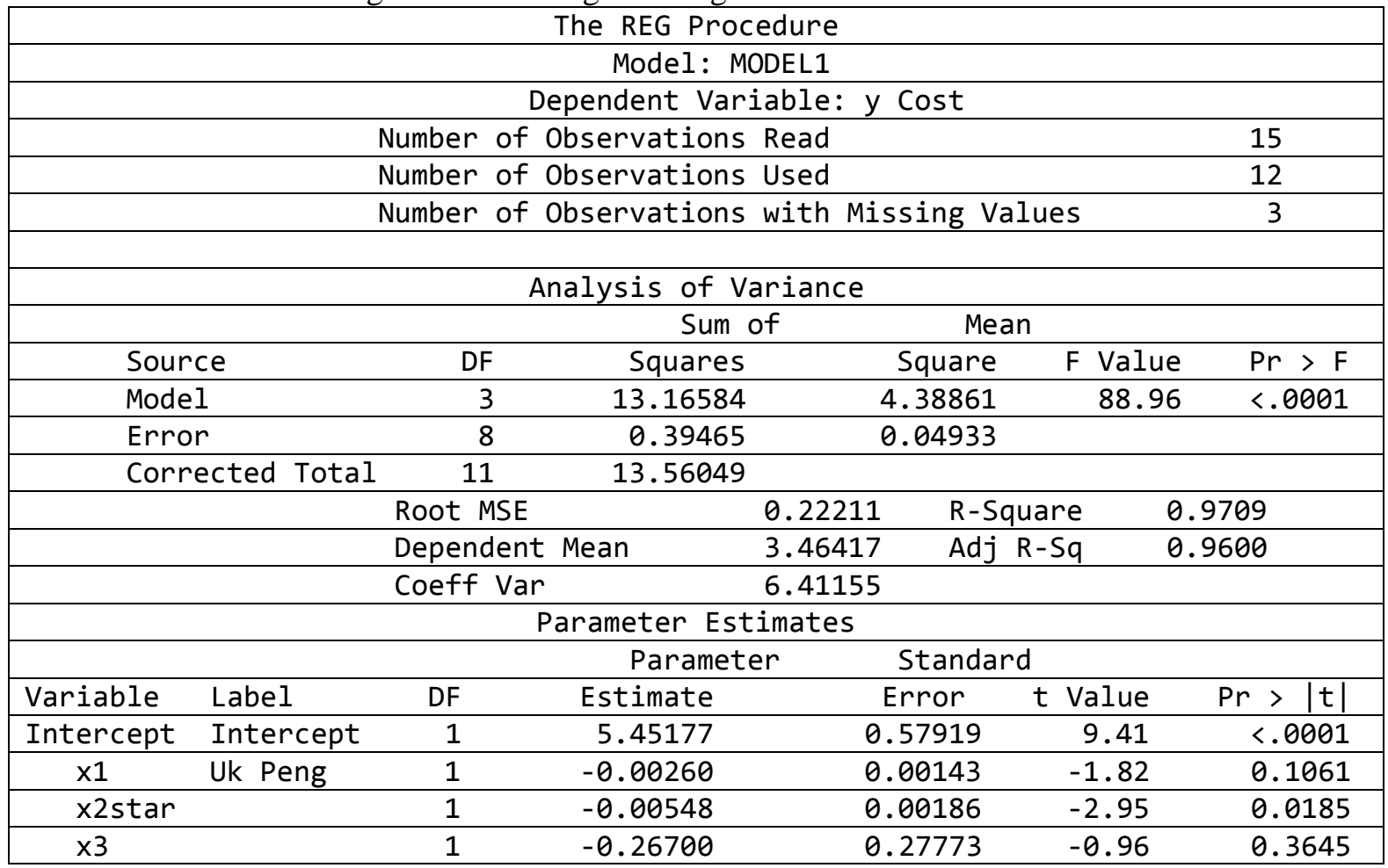

Nilai $\mathrm{R}^{2}$ untuk fungsi tidak kontinu adalah 0.9709 lebih besar dari $\mathrm{R}^{2}$ fungsi kontinu. Berarti untuk kasus ini regresi tersegmen dengan fungsi tidak kontinu lebih baik dari regresi tersegmen dengan fungsi kontinu.

\section{Kesimpulan}

Berdasarkan uraian di atas, dapat disimpulkan bahwa untuk titik patahan diketahui model yang diperoleh dari analisis regresi linier tersegmen fungsi kontinu memberikan nilai koefisien determinasi lebih besar dibandingkan model regresi linier sederhana, yang berarti bahwa model regresi linier tersegmen mampu menjelaskan keragaman data lebih besar dari keragaman yang bisa dijelaskan oleh model regresi linier sederhana. Selain itu, untuk kasus ini regresi tersegmen dengan fungsi tidak kontinu lebih baik dari regresi tersegmen dengan fungsi kontinu.

\section{Daftar Pustaka}

[1] Anonymous. 2006. Segmented Regression. http://en.wikipedia.org/wiki/Segmented_regression

[2] Diniz, C.A.R and L.C. Brochi. 2005. Robustness of Two-Phase Regression Tests. REVSTAT-Statistical Journal 3:3 http://www.ine.pt/revstat/pd

[3] Khoirun, I.F. 2011. Pendugaan kecepatan arus sungai dengan menggunakan regresi piecewise (studi kasus sungai soos creek di negara bagian Washington). Skripsi Departemen Statistika FMIPA IPB

[4] Oosterbaan, R.J., D.P. Sharma and K.N. Singh. 1990. Crop production and soil salinity:Evaluation of field data from India by segmented linear regression. Symposium on Land Drainage for Salinity Control in Arid and Semi-Arid Regions.Vol.3.Cairo http://waterlog.info/pdf/segmregr.pdf

[5] Ryan, S.E. and L.S.Porth. 2007. A Tutorial on the Piecewise Regression Approach Applied to Bedload Transport Data. General Technical Report RMS-GTR-189 http://www.fs.fed.us/rm/pubs/rmrs_gtr189.pdf

[6] Shofiyati, Arina. 2008. Kajian Analisis Regresi Linier Tersegmen. Skripsi Jurusan Statistika Fakultas Matematika dan Ilmu Pengetahuan Alam Universitas Brawijaya. Malang. 